Original Research

\title{
Demographical Factors, Not Lifestyle Factors, Associated with the Increase of Random Blood Glucose in Coastal Areas
}

\section{Nilam Yusika Sari, Susy K. Sebayang, Septa Indra Puspikawati, Desak Made Sintha Kurnia Dewi, Ayik M. Mandagi and Erni Astutik}

Faculty of Public Health, Universitas Airlangga, Banyuwangi, Indonesia

\begin{abstract}
Introduction: Blood glucose is an important component in the body produced by the consumption of carbohydrates, proteins, and fats. A blood glucose imbalance causes an increase in the blood glucose level in the body. The occurrence of economic changes due to tourism may lead to a change in diet that can lead to increased blood glucose levels. This study aims to analyse the factors related to random blood glucose in people living in coastal tourism areas in Banyuwangi
\end{abstract}

Methods: The study used a cross-sectional survey. A total of 112 respondents were recruited using the random sampling method, using two-stage cluster sampling techniques taken from the Head of household data in multiple villages. The factors studied included demographic, socioeconomic, lifestyle, and family health history.

Results: The results showed that men had $28 \%$ higher random blood glucose compared to woman. People living in Bangsring had 31\% higher random blood glucose compared to those in Buluagung.

Conclusion: Local health care services should put extra effort into include men and those living in Bangsring in programs to prevent Diabetes Mellitus in coastal areas.

\section{ARTICLE HISTORY}

Received: April 19, 2018

Accepted: June 22, 2018

\section{KEYWORDS}

random blood glucose; coastal area; tourism

\section{CONTACT}

Erni Astutik

凶erniastutik@fkm.unair.ac.id

$\equiv$ Faculty of Public Health,

Universitas Airlangga,

Banyuwangi, Indonesia

Cite this as: Sari, N., Sebayang, S., Puspikawati, S., Dewi, D., Mandagi, A., \& Astutik, E. (2018). Demographical Factors, Not Lifestyle Factors, Associated with the Increase of Random Blood Glucose in Coastal Areas. Jurnal Ners, 13(1), 87-92. doi:http://dx.doi.org/10.20473/jn.v13i1.8148

\section{INTRODUCTION}

Diabetes Mellitus is now a serious health problem in the community. This disease has become a burden on a global level. Since 2000, the World Health Organisation (WHO) estimated that Asia would become the continent with the world's largest number of Diabetes Mellitus sufferers, reaching 82 million people. The number would continue to increase for the next 25 years (Sucipto, 2012). Meanwhile, Diabetes Mellitus prevalence in Indonesia had increased by $1 \%$ from 2007 to 2013. The three provinces with the highest frequency of Diabetes Mellitus are Yogyakarta, Jakarta and North Sulawesi (Fehni et al., 2017).

People with random blood glucose are at a higher risk of developing Diabetes Mellitus. Uncontrolled Diabetes Mellitus disease can have both long-term and short-term effects that are harmful to overall health. Long-term effects that may occur include the emergence of other degenerative diseases, such as heart disease, stroke, nerves, kidneys, and other health disorders. Meanwhile, in the short term, Diabetes Mellitus causes visual disturbances, fatigue, frequent thirst, and increased urination (Arif, 2014). In addition, this disease can affect quality of life. Efforts to manage living with Diabetes Mellitus are not easy and can even cause stress, triggered by the fear of complications (American Diabetes Association, 2000).

The increase of Diabetes Mellitus is not only happening in urban areas, but also in rural, coastal and tourism areas. Tourism indirectly affects the health of the community living near to the tourism destination. Influential factors such as age, sex, education, occupation, lifestyle, and health history play an important role. This needs to be resolved and a solution found in order to maintain optimal public health status. 
There are many items of literature that have analysed the determinants of high blood glucose. A study conducted by Sudaryanto (2014) states that those with a family health history of high blood glucose levels had a 25-fold chance of the incidence of Type II Diabetes Mellitus in the working area of the community health centre of Nusukan, Banjarsari. In addition, there was also a relationship between age and the incidences of Diabetes Mellitus in the community health centre of Nipah Panjang East Jabung regency, with those aged $>45$ years having the highest risk (Erris, 2015). A study conducted by Wicaksono (2011) showed that those who were overweight respondents had double, those with smoking habits had triple, and those with bad dietary pattern had double the risk of developing type II Diabetes Mellitus.

However, studies on the determinant of high blood glucose level in coastal tourism areas in Indonesia are scarce. This has become an important problem, considering the increasing number of coastal tourism destinations. Economic improvements in the coastal tourism areas may change dietary patterns and lifestyle, and thus increase the overall blood glucose level of the community. Therefore, this study assessed the determinants of elevated blood glucose levels in people living in coastal tourism areas in Banyuwangi, which included demographic, socioeconomic, lifestyle, and family history factors.

\section{MATERIALS AND METHODS}

This study analysed the data taken from the results of a cross-sectional survey that assessed the factors related to Metabolic Syndrome in people living in coastal tourism areas in Banyuwangi. The survey was conducted from September to November 2016. The survey was approved by the Ethics Committee of the Faculty of Public Health, Universitas Airlangga.

\section{Sampling}

Two-stage cluster sampling was employed in order to select the participants. Participating subdistricts included all of the 5 sub-districts with coastal tourism destinations in Banyuwangi. Of the 52 villages in the participating sub-districts, 22 villages had a coastline and thus fell within the selection criteria. Based on this, 5 villages were randomly selected to become the study locations: Kampung Mandar (Banyuwangi Sub-district), Ketapang (Kalipuro Sub-district), Grajagan (Purwoharjo Subdistrict), Bangsring (Wongsorejo Sub-district), and Buluagung (Siliragung Sub-district). A sample of 112 respondents were randomly selected from a list of Heads of the household. The inclusion criteria were that the participants were within the age range of 18 - 59 years old, and looked healthy. The number of samples was sufficient enough to detect a $67 \%$ difference in the proportion of the determinants of elevated blood glucose levels with a 5\% error, $90 \%$ power, 2 design effects and $25 \%$ rejection probability (Lemeshow et al, 1990).

\section{Data Collection}

The data was collected by trained officers consisting of students with a Public Health Science background who had taken at least 3 semesters of university-level education. Blood collection was done by a trained nurse using Accu Check. Anthropometric measurements were performed by the students using SECA 213 for stature and SECA 869 for the scales. The participant's mental and emotional status was measured using a Self-Reported Questionnaire used by the National Survey in Indonesia (Basic Health Research, 2007). The research questionnaire was tested for validity and reliability in Kepatihan Village in Banyuwangi District on October 1st, 2016. The Cronbach alpha was 0.72 . The questionnaire was found to be valid as the $r$ count was greater than the $r$ table.

\section{Data Analysis}

The dependent factor in this study was random blood glucose. This was transformed using log transformation because the distribution was skewed to the right. The independent factors consisted of demographic factors (age, sex, location), socioeconomic factors (education level, occupation, socioeconomic status), lifestyle factors (smoking habit, stress level and nutritional status) and family health history, which included any one of the three following diseases: Diabetes Mellitus, high blood pressure, and obesity.

The demographic factors included age, sex, and location. Age was categorised into: young ( $<43$ years) and old ( $\geq 43$ years) based on the median value. Sex was divided into men and women. The location of the research were the five aforementioned study locations. The socioeconomic factors included levels of education: low (no school, not finished primary school, finished primary school), medium (finished junior high school or high school), and high (had higher education). Occupation was categorised into not working and working. Wealth status was obtained using a Principal Component Analysis of the respondent's asset ownership and was grouped into very poor, poor, medium, rich, and very rich. Lifestyle factors included smoking habits (smoking and nonsmoking), as well as mental-emotional status score: low (value $<6$ ) and high (value $\geq 6$ ); and nutritional status: normal (BMI $<24.9$ ) and overweight $(\geq 25)$. Family health history was divided into their relatives having at least one history of disease and not having any history of hypertension, obesity, and Diabetes Mellitus.

Bivariate and multivariate analysis was done using a Linear Regression Test. The factors that have an association with blood glucose level with $\mathrm{p}<0.25$ 
Table 1. Characteristics of Respondents

\begin{tabular}{|c|c|c|c|}
\hline Factor & Frequency & Percentage (\%) & Means (log Blood Glucose) \\
\hline \multicolumn{4}{|l|}{ Demographic Factors } \\
\hline \multicolumn{4}{|l|}{ Age } \\
\hline Young $<43$ years & 53 & 47.3 & 4.63 \\
\hline Old $\geq 43$ years & 59 & 52.7 & 4.79 \\
\hline \multicolumn{4}{|l|}{ Sex } \\
\hline Female & 67 & 59.8 & 4.60 \\
\hline Male & 45 & 40.2 & 4.89 \\
\hline \multicolumn{4}{|l|}{ Location } \\
\hline Buluagung & 18 & 16.1 & 4.56 \\
\hline Kampung Mandar & 19 & 17 & 4.80 \\
\hline Ketapang & 21 & 18.8 & 4.78 \\
\hline Bangsring & 30 & 26.8 & 4.77 \\
\hline Grajagan & 24 & 21.4 & 4.64 \\
\hline \multicolumn{4}{|c|}{ Socio-Economy Factors } \\
\hline Low & 27 & 24.1 & 4.64 \\
\hline Medium & 69 & 61.6 & 4.70 \\
\hline High & 16 & 14.3 & 4.92 \\
\hline \multicolumn{4}{|l|}{ Work } \\
\hline Not Working & 46 & 41.1 & 4.70 \\
\hline Working & 66 & 58.9 & 4.73 \\
\hline \multicolumn{4}{|l|}{ Social Economy } \\
\hline Very Rich & 20 & 17.9 & 4.62 \\
\hline Rich & 21 & 18.8 & 4.70 \\
\hline Medium & 26 & 23.2 & 4.75 \\
\hline Poor & 21 & 18.8 & 4.77 \\
\hline Very Poor & 24 & 21.4 & 4.76 \\
\hline \multicolumn{4}{|l|}{ Life Style Factors } \\
\hline \multicolumn{4}{|l|}{ Smoking } \\
\hline Smoking & 21 & 18.8 & 4.72 \\
\hline Non-Smoking & 91 & 81.3 & 4.69 \\
\hline \multicolumn{4}{|l|}{ Stress Level } \\
\hline High $>=6$ & 29 & 25.9 & 4.69 \\
\hline Low $<6$ & 83 & 74.1 & 4.72 \\
\hline \multicolumn{4}{|c|}{ Nutritional Status Based On IMT } \\
\hline Normal & 42 & 37.5 & 4.70 \\
\hline Overweight & 70 & 62.5 & 4.72 \\
\hline \multicolumn{4}{|c|}{ Family Health History Factors } \\
\hline With History & 28 & 25.0 & 4.70 \\
\hline No History & 84 & 75.0 & 4.72 \\
\hline
\end{tabular}

were included in the multivariate analysis. The final regression model was selected using a backward elimination technique. The assumption for regression was also tested.

\section{RESULTS}

The study was conducted with the participation of 112 respondents, $99.1 \%$ of which had breakfast before their blood was drawn.The results showed that $52.7 \%$ of the respondents were $\geq 43$ years old. More than half of the respondents were women (59.8\%) and the largest number of respondents came from Bangsring (26.8\%). The least number came from Buluagung (16.1\%). Most of the respondents had a medium level of education, i.e. they had attended junior and senior high school (61.6\%) and most of the respondents worked (58.9\%). For the lifestyle factors, most of the respondents did not smoke (81.3\%) and $25.9 \%$ had a high-stress level. In addition, most of the respondents were overweight $(80.4 \%)$. When viewing the family health history, $75 \%$ of the respondents did not have any history of health problems associated with increased blood glucose in their family (Table 1).

Based on the bivariate analysis, age, gender, location, education, and social economy were associated with random blood glucose with a p-value $<0.25$. After backward elimination was conducted in the multivariate analysis, sex and location had a significant relationship with increased random blood glucose. Age was maintained in the final model because of its confounding with gender. When we used age as a continuous variable, the association remained insignificant. After adjustment for the covariates, the male respondents had 28\% higher blood glucose levels than the women (95\% CI: 10.5 49.2, $\mathrm{p}<0.001)$.The respondents in Bangsring had $31 \%$ higher blood glucose levels than those in Buluagung (95\% CI: 5.1 - 61.6, $\mathrm{p}=0.02$ ).

\section{DISCUSSION}

Our study showed that there was a significant relationship between increased random blood glucose levels and the demographic factors 
Table 2. Determinants of Increased Random Blood Glucose Levels

\begin{tabular}{|c|c|c|c|c|c|c|c|}
\hline Factors & Category & Coef. & 95\% CI & $\begin{array}{c}P \\
\text { Value }\end{array}$ & $\begin{array}{c}\text { Adjusted } \\
\text { Coefficient }\end{array}$ & $95 \% \mathrm{CI}$ & $\begin{array}{c}\mathbf{P} \\
\text { Value }\end{array}$ \\
\hline \multicolumn{8}{|c|}{ Demographic Factors } \\
\hline \multirow[t]{2}{*}{ Age } & $<43$ years & Ref & & & Ref & & \\
\hline & $\geq 43$ years & 0.17 & $0.02-0.31$ & 0.03 & 0.12 & $-0.04-0.27$ & 0.13 \\
\hline \multirow[t]{2}{*}{ Sex } & Female & Ref & & & Ref & & \\
\hline & Male & 0.29 & $0.15-0.43$ & 0.00 & 0.25 & $0.10-0.40$ & 0.00 \\
\hline \multirow[t]{5}{*}{ Location } & Buluagung & Ref & & & Ref & & \\
\hline & KampungMandar & 0.24 & $-0.01-0.49$ & 0.06 & 0.23 & $-0.10-0.46$ & 0.06 \\
\hline & Ketapang & 0.22 & $-0.03-0.47$ & 0.08 & 0.20 & $-0.03-0.43$ & 0.08 \\
\hline & Bangsring & 0.20 & $-0.02-0.43$ & 0.08 & 0.27 & $0.05-0.48$ & 0.02 \\
\hline & Grajagan & 0.08 & $-0.16-0.32$ & 0.50 & 0.07 & $-0.15-0.29$ & 0.54 \\
\hline \multicolumn{8}{|c|}{ Socio-Economy Factors } \\
\hline \multirow{4}{*}{$\begin{array}{c}\text { Level of } \\
\text { Education }\end{array}$} & & & & & & & \\
\hline & Low & Ref & & & & & \\
\hline & Medium & 0.06 & $-0.11-0.24$ & 0.49 & & & \\
\hline & High & 0.29 & $0.05-0.53$ & 0.02 & & & \\
\hline \multirow[t]{2}{*}{ Work } & Not Working & Ref & & & & & \\
\hline & Working & 0.02 & $-0.13-0.17$ & 0.80 & & & \\
\hline \multicolumn{8}{|l|}{ Social } \\
\hline \multirow[t]{5}{*}{ Economy } & Very Rich & Ref & & & & & \\
\hline & Rich & 0.08 & $-0.15-0.32$ & 0.49 & & & \\
\hline & Medium & 0.13 & $-0.09-0.35$ & 0.24 & & & \\
\hline & Poor & 0.16 & $-0.08-0.39$ & 0.19 & & & \\
\hline & Very Poor & 0.13 & $-0.09-0.38$ & 0.28 & & & \\
\hline \multicolumn{8}{|l|}{ Life Style Factors } \\
\hline \multirow[t]{2}{*}{ Smoking } & Smoking & Ref & & & & & \\
\hline & Non Smoking & 0.05 & $-0.15-0.24$ & 0.64 & & & \\
\hline \multirow[t]{2}{*}{ Stress Level } & High $>=6$ & Ref & & & & & \\
\hline & Low $<6$ & 0.03 & $-0.13-0.20$ & 0.69 & & & \\
\hline \multicolumn{8}{|l|}{$\begin{array}{c}\text { Nutritional } \\
\text { Status Based }\end{array}$} \\
\hline \multirow[t]{2}{*}{ On IMT } & Weigt & Ref & & & & & \\
\hline & Overweight & 0.02 & $-0.13-0.17$ & 0.80 & & & \\
\hline \multicolumn{8}{|l|}{$\begin{array}{l}\text { Family Health } \\
\text { History Factors }\end{array}$} \\
\hline & With History & Ref & & & & & \\
\hline & No History & 0.03 & $-0.15-0.20$ & 0.77 & & & \\
\hline
\end{tabular}

represented by sex and the location of the study, but not with socioeconomic status, lifestyle, or family health history. The male respondents had higher random blood glucose levels compared to women, and those living in Bangsring village had higher random blood glucose levels than those living in Buluagung.

Our results showing that men had more elevated blood glucose levels compared to women, which is not in line with the research conducted by Wicaksono (2011) and Tjekyan in the Palembang Municipality (2010). Another study showed that women experience more dramatic changes in relation to hormones and their bodies due to the reproductive factors that fluctuate over the duration of their lifetime. Therefore, women have higher blood glucose levels than men (Willer, et al., 2016). In addition, another study focused on the coastal area of India showed that women had a 1.4 times greater risk of mild diabetes (Rao et al., 2010), which is different from our results. However, in line with our study, Ohtaet al. (2014) showed that increased levels of blood glucose characterised by hyperglycemia occurred faster in male compared to female rats.
We cannot offer an explanation as to why men had higher blood glucose level compared to women in our study, other than the possibility of having a higher food intake during breakfast. Those living in Bangsring had higher blood glucose levels compared to Buluagung. Although not statistically significant, those living in Ketapang and Kampung Mandar also had similar estimates to Bangsring. Two possible explanations for this was that people in these villages depend more on fishing and have a lower socioeconomic status. The lack of association between random blood glucose and lifestyle may indicate that the lifestyle factors may not have changed much within this particular community.

To date, this is the first study on random blood glucose level focused on the coastal areas of Banyuwangi. The advantages of this study are that we assessed various determinants, including the demographic, social economy, lifestyle, and family health history factors. The study, however, did not measure fasting and two hours post-prandial blood glucose level. Therefore, it is not known with certainty the tendency for Diabetes Mellitus. However, random blood glucose tests were been used 
to screen for Diabetes Mellitus. In addition, the study did not measure food intake and thus, we could not take into account this important factor as a possible determinant.

The results showed that men and those living in Bangsring Village may need extra attention when it comes to Diabetes Mellitus prevention programs. A previous research study showed that more women in the community sought access to the available health care services compared to men (Sebayang, 2017). The large number of men with potential Diabetes Mellitus may neglect their health, and this must be addressed immediately. One thing that can be done is to optimise the implementation of Posbindu PTM (Integrated Non-Communicable Disease Management Post) for both women and men with anthropometric measurements, blood pressure measurements, blood glucose checks, cholesterol checks and health counselling regularly and periodically, especially for those living in Bangsring. Future studies need to look for changes in food intake in this community and to assess its possible impact on health.

\section{CONCLUSION}

Research conducted in the coastal tourism areas of Banyuwangi showed that demographic factors had a significant association with elevated random blood glucose levels in the male respondents. Those living in Bangsring also had a higher random blood glucose. The health care system should make an extra effort to include men and those living in Bangsring in their Diabetes Mellitus prevention program.

\section{REFERENCES}

Badan Pusat Statistik Kabupaten Banyuwangi. (2014). Banyuwangi Dalam Angka Tahun In Figures 2014. Banyuwangi: BPS Kabupaten Banyuwangi.

Badan Penelitian dan Pengembangan Kesehatan Kementrian Kesehatan RI. (2013). Riskesdas Biomedis: Riset Kesehatan Dasar 2013. pdf

Dolongseda, F.V. dkk. (2017). Hubungan Pola Aktivitas Fisik Dan Pola Makan Dengan Kadar Gula Darah Sewaktu Pada Pasien Diabetes Mellitus Tipe II Di Poli Penyakit Dalam Rumah Sakit Pancaran Kasih GMIM Manado. Journal Keperawatan (E-Kp). Volume 5 Nomor 1, Februari 2017.

Erris. (2015). Faktor Risiko Kejadian Diabetes Mellitus Di Wilayah Kerja Puskesmas Nipah Panjang Kabupaten Tanjung Jabung Timur Tahun 2015. Scientia JournalStikes Prima Jambi. Nomer 3 Volume 4 Desember 2015.

Kurniawan, I. (2014). Hubungan Antara Indeks Masa Tubuh Dengan Kadar Gula Darah Prospandial Pada Anggota Kepolisian Resor Karanganyar. Naskah Publikasi Ilmiah Fakultas Kedokteran Universitas Muhammadiyah Surakarta.

Kusuma, B.M.A. (2014). Pembangunan Terintegrasi Dalam Mewujudkan Kota Pariwisata Bertaraf Internasional: Studi Kasus Di Kabupaten Banyuwangi Jawa Timur. JKMP (ISSN. 2338-445x)
Volume 2 Nomer 2 September 2014 halaman 103220.

Kementrian Kesehatan Republik Indonesia. (2014). INFODATIN: Situasi dan Analisis Diabetes. Jakarta Selatan: Pusat Data dan Informasi Kementrian Kesehatan Republik Indonesia.

Laila, Alfi, dkk. (2017). Analisis Faktor-Faktor Risiko Kejadian Katarak Di Daerah PesisirKendari.

Volume 4 Nomor 2 Bulan April 2017 ISSN: 23391006.

Lanywati, E. (2001).Diabetes Mellitus Penyakit Kencing Manis.Yogyakarta: Penerbit Kanisius.

Murdiyatmoko, J. (2007). Sosiologi: Memahami Dan Mengkaji Masyarakat. Bandung: PT. Grafindo Media Pratama.

Nugroho, dkk. (2010). Hubungan Antara Tingkat Stress Dengan Kadar Gula Darah Pada Pasien Diabetes Mellitus Di Wilayah Kerja Puskesmas Sukoharjo I Kabupaten Sukoharjo. pada tanggal 26 Desember 2017).

Ohta, dkk. (2014). Gender Differences In Metabolic Disorder And Related Diseases In Spontaneously Diabetic Torii-Lepr ${ }^{\mathrm{fa} R a t s . J o u r n a l}$ of Diabetes Research. Website: https://www.ncbi.nlm.nih.gov/pmc/articles/PM C4033479/(Accessed : March 01,2018).

Pangkalan Ide. (2007). Diet South Beach: Gendut, No Way! KurusTapiBeresiko? Nggak-Lah. Aduhai Tanpa Diabetes Sih Oke. Jakarta. PT. Elex Media Komputindo Kelompok Gramedia. ISBN: 78-97927-0203-3.

Prabowo, dkk. (2015). Hubungan Pendidikan Dan Dukungan Keluarga Dengan Kepatuhan Diit Pada Penderita Diabetes Mellitus Di Wilayah Puskesmas Plosorejo Giribangun Matesih Kabupaten Karanganyar. ___ . Program Studi Diploma III Ilmu Keperawatan Sekolah Tinggi Ilmu Kesehatan PKU Muhammadiyah Surakarta.

Rao, dkk. (2010). A Study on the Prevalence Of Type 2 Diabetes In Coastal Karnataka. Int J Diabetes Ctries, 30. Diakses pada tanggal 23 Juni 2018. Website: https://www.ncbi.nlm.nih.gov/pmc/articles/PM C2878695/(Accessed : March 01,2018).

Salami. (2017). Faktor Sosiodemografi Dan Self Efficacy Penderita Diabetes Mellitus Tipe 2 (Study Pada Peserta Prolanis) Di Puskesmas Talaga Bodas Bandung. Medika Cendikia. Volume 4 Nomer 12017.

Sudaryanto. dkk. (2014). Hubungan Antara Pola Makan, Genetik Dan Kebiasaan Olahraga Terhadap Kejadian Diabetes Mellitus Tipe II Di Wilayah Kerja Puskesmas Nusukan, Banjarsari. Prosiding SNST Ke-5 Tahun 2014 Fakultas Teknik Universitas Wahid Hasyim Semarang ISBN 978602-99334-3-7.

Sebayang, S. K., dkk. (2017). Health Care-Seeking Behaviour of Coastal Communities in Banyuwangi, Indonesia: Results of A Cross-Sectional Survey. Jurnal Ners, 12 (1), pp.66-73.

Tjekyan dan Suryadi. (2014). Angka Kejadian dan Faktor Risiko Diabetes Mellitus Tipe 2 Di 78 RT 
Kotamadya Palembang Tahun 2010. MKS. Tahun 46 Nomer 2, April 2014.

Wijayakusuma, M. Hembing. (2004). Bebas Diabetes Mellitus Ala Hembing. Jakarta: PuspaSwara.

Wicaksono, R.P. (2011). Faktor-Faktor Yang Berhubungan Dengan Kejadian Diabetes Mellitus Tipe 2(StudiKasus Di Poliklinik Penyakit Dalam Rumah Sakit Dr.Kariadi). Skripsi. Program Pendidikan Sarjana Kedokteran Fakultas Kedokteran Universitas Diponegoro.

Wiyadi, dkk. (2013). Hubungan Tingkat Kecemasan Dengan Kadar Gula Darah Pada Penderita Diabetes Mellitus. Jurnal Husada Mahakam. Volume III nomer 6 Nopember 2013 halaman 263318.
Willer, dkk. (2016). Sex And Gender Differences in Risk, Pathophysiology And Complications Of Type 2 Diabetes Mellitus. Journal Endocr Rev, 37, pp.278-316. Diakses pada tanggal 23 Juni 2018. Website:

https://www.ncbi.nlm.nih.gov/pmc/articles/PM C4890267/(Accessed : March 01,2018).

Wulandari, dkk. (2013). Perbedaan Kejadian Komplikasi Penderita Diabetes Mellitus Tipe 2 Menurut Gula Darah Acak. Jurnal Berkala Epidemiologi. Volume 1 Nomer 2 September 2013 halaman 182-191.

Yanita, dkk. (2016). Faktor-Faktor yang Berhubungan dengan Kejadian Diabetes Mellitus Tipe II. Majority. Volume 5 Nomer 2 April 2016. 